Pesq. Vet. Bras. 38(1):89-93, janeiro 2018

DOI: $10.1590 /$ S0100-736X2018000100014

\title{
Stray dogs in urban fragments: relation between population's perception of their presence and socio-demographic factors ${ }^{1}$
}

\author{
Aline G.A. Guilloux ${ }^{2 *}$, Ligia I. Panachão², Ana J.S. Alves², Carolina B. Zetun², Alex J.F. \\ Cassenote $^{3}$ and Ricardo A. Dias ${ }^{2}$
}

\begin{abstract}
Guilloux A.G.A., Panachão L.I., Alves A.J.S., Cassenote A.J.F. \& Dias R.A. 2018. Stray dogs in urban fragments: relation between population's perception of their presence and socio-demographic factors. Pesquisa Veterinária Brasileira 38(1):89-93. Departamento de Medicina Veterinária Preventiva e Saúde Animal, Faculdade de Medicina Veterinária e Zootecnia, Universidade de São Paulo, Av. Prof. Dr. Orlando Marques de Paiva 87, Cidade Universitária, São Paulo, SP 05508-270, Brazil. E-mail: aline_gil@hotmail.com

Stray dogs are associated with environment and public health impacts. São Paulo is a city with approximately 2.5 million owned dogs and until the time of writing no studies describing the distribution of the stray dog population have been conducted in this city. Therefore, no scientific support for intervention plans is available. The objective of this study was to evaluate the association of local sociodemographic and environmental factors with the population perception of presence of stray dogs in urban fragments of São Paulo city. A convenience sample of six urban fragments was selected. In-depth interviews were performe, using a systematic random sample of households in each study area, between October/2010 and January/2011 to identify socio-demographic factors of interest and determine the population's perception of stray dogs. Additionally, the presence of stray dogs was estimated by photographic mark-recapture method. The degree of human-dog proximity and environmental factors such as waste handling were associated to the sighting of stray dogs. Stray dogs were observed in two of the six study areas, agreeing with the greater population perception of this issue on those areas. Intervention in these factors and encouragement of responsible ownership are two potential solutions for management and reduction of problems associated with the presence of stray dogs.
\end{abstract}

INDEX TERMS: Stray dogs, São Paulo, relinquishment, carrying capacity, responsible ownership.

RESUMO.- [Cães errantes em fragmentos urbanos: relação entre o relato de visualização de cães errantes e fatores sociodemográficos da população local.] A presença de cães errantes está associada a impactos no meio ambiente e na saúde pública. São Paulo é uma cidade com aproximadamente 2.5 milhões de cães domiciliados e até o presente momento, não foram desenvolvidos estudos que descrevam a distribuição da população errante na cidade.

\footnotetext{
${ }^{1}$ Received on July 24, 2015.

Accepted for publication on November 24, 2016.

${ }^{2}$ Departamento de Medicina Veterinária Preventiva e Saúde Animal, Faculdade de Medicina Veterinária e Zootecnia, Universidade de São Paulo. Av. Prof. Dr. Orlando Marques de Paiva, 87. Cidade Universitária, São Paulo, SP. Cep 05508-270, Brazil. *Corresponding author: aline.gil@usp.br

${ }^{3}$ Programa de Pós-Graduação em Doenças Infecciosas e Parasitárias, Faculdade de Medicina, Universidade de São Paulo. Av. Dr. Enéas de Carvalho Aguiar, 470, Térreo: sala 06. Cerqueira Cesar, São Paulo - SP. Cep 05403000, Brazil.
}

Desta forma, não há suporte científico para planejar intervenções. 0 objetivo deste estudo foi avaliar a associação entre os fatores sociodemográficos e ambientais da população local com a frequência com que relataram a visualização de cães errantes em fragmentos urbanos da cidade de São Paulo. Foi definida uma amostra de conveniência composta por seis fragmentos urbanos, onde um questionário foi aplicado em uma amostra sistemática dos domicílios de cada área de estudo. Este questionário, aplicado entre outubro de 2010 e janeiro de 2011, determinou os fatores socio-econômicos de interesse e a percepção da presença de cães errantes pela população. Também foi estimada a presença de cães pelo método de marcação e recaptura fotográfica. Foi possível estabelecer uma relação entre a visualização de cães errantes pela população local e o grau de proximidade com cães e o manejo de resíduos do domicílio. Cães errantes foram observados em duas das seis áreas trabalhadas, em concordância com a maior percepção da sua 
presença pela população local. Intervenções nestes fatores e incentivo a guarda responsável são duas ações com potencial de contribuir para redução dos problemas causados pela presença de cães errantes.

TERMOS DE INDEXAÇÃO: Cães errantes, São Paulo, abandono, capacidade de suporte, guarda responsável.

\section{INTRODUCTION}

When human population began caring for and domesticating animals, they became responsible for regulating their reproduction (Jöchle 1991). Failure to meet this need has several consequences, among them the growing unsupervised population of dogs roaming in public places. This population represents a public health and environmental risk as these animals may cause environmental pollution, dog bite injuries, be involved in predation, traffic accidents and zoonotic disease transmission (Rubin \& Beck 1982, Kato et al. 2003, Dalla Villa et al. 2010).

The role of dogs in transmitting urban rabies to humans especially in South America, Asia and Africa emphasises the importance of controlling the unsupervised dog population. In 1973, the Brazilian government created a program for rabies control that included capturing and euthanising roaming dogs (Pozzetti 2001). This practice was used even after human rabies eradication in São Paulo city, in 1984.

São Paulo is a city with approximately 2.5 million owned dogs and a human population over 11 million people (Canatto 2010, IBGE 2015). In 2008, the authorities forbade euthanasia of healthy, unaggressive pets captured by the public zoonosis control center (Sao Paulo State Law 12.916), attempting to control them through sterilisation and encouragement of responsible ownership.

The dogs now captured by the authorities are sterilised and directed to adoption, a process that may take years. Dogs once kept for a few days before euthanasia are now kept for much longer periods of time. The housing capacity of public dog shelters has not changed with the law, leading to the inability to meet the demand of capturing stray dogs. In São Paulo there is no public shelter with capacity to meet this demand, which has likely resulted in abandonment of dogs in the streets and subsequent growth of the stray dog population.

Despite the fact that the capture of stray dogs has occurred since 1889 (São Paulo City Law 390), until the time of writing, no study determined the distribution or the size of the stray dog population in this city neither the characteristics of people relinquishing or abandoning dogs. Our study aims to associate social and demographic factors of the human population, characteristics of the owned dog population and environmental factors with the population perception of stray dogs in urban fragments of São Paulo. This could help to provide a scientific base for intervention plans in this field.

\section{MATERIALS AND METHODS}

Scenario and study design. Between October 2010 and January 2011, a cross-sectional study was conducted in urban areas of São Paulo city. Six out of the 96 districts of São Paulo city were chosen at convenience for having different sociodemographic characteristics, such as number of dogs per household (Canatto 2010), number of dog bites per person (SINAN 2009), number of households that intended to reduce the number of owned dogs (Canatto 2010), as shown in Table 1. In the sampled districts, we chose closed areas, limited by continuous walls, water bodies or main avenues that would restrict dog's movement in and out of the study areas. Dogs were considered stray when in public places without direct human supervision.

We used photographic mark-recapture method to estimate the number of dogs in each study area (Beck 1973). We established routes that included all the streets of each study area that were covered by car (at a $30 \mathrm{~km} /$ hour velocity). Each area was visited four times in the same week, two in the morning and two in the afternoon (between 9 and 11 am and between 3 and 5 pm respectively) in clear days. Each dog was photographed and briefly described allowing it to be identified as a unique dog and recognized if photographed a second time. The mathematical method described by Beck (1973) was used to calculate the number of stray dogs in each area.

Also a 20 minute questionnaire was applied in a systematic sample of 20 households in each study area. One adult person (over 18 years of age) from the household answered a personal interview regarding characteristics of human and dog housing, the dog keeper, the dog itself (in the owner's perception) and handling of household waste. It also included the householder's perception about the environment in that specific study area. The questionnaire was developed to evaluate relinquishment risk factors that could influence abandonment based on the available scientific literature (Rubin \& Beck 1982, Kidd et al. 1992, Patronek et al. 1996, New Jr. et al. 2000, Pozzetti 2001, Kato et al. 2003, Weng et al. 2006, Marder \& Duxbury 2008, Reece et al. 2008, Dias et al. 2013) and environmental maintenance of the stray dog population. It was designed with 50 closed-ended questions - 18 applying to all households visited and 32 only to household with dogs.

To test the questionnaire, it was first applied to colleagues at University of São Paulo, then to University's employees and then to clients of the University's veterinary hospital. After that, a pilot study was performed in an area similar to the study areas and the questionnaire was finalised. The three people that performed the interviews were trained so as to avoid bias on interviews.

Database and statistical analysis. Data was analysed through multilevel mixed-effects Poisson regression, with the areas as grouping variable to compare the perception of presence of stray dogs (as established in the questionnaire) and relinquishment risk factors. The correlation between risk factors was estimated through the Spearman method. Variables that showed association with the presence of stray dogs in a significance level $(p)$ below 0.2 (two-tailed) were used in a multiple analysis.

Table 1. Characteristic of districts used as selection factor for study areas: average number of dogs per household ${ }^{\mathrm{a}}$, number of dog bites by 1,000 people in $2008^{\mathrm{b}}$ and percent of households intending to reduce the number of dogs they housed $^{\text {a }}$. São Paulo, 2011

\begin{tabular}{lccc}
\hline Area & $\begin{array}{c}\text { N dogs/ } \\
\text { household }\end{array}$ & $\begin{array}{c}\text { Dog bites/ } \\
1,000 \text { people }^{\mathrm{b}}\end{array}$ & $\begin{array}{c}\text { \% Intended } \\
\text { to reduce }\end{array}$ \\
\hline Area 1 $^{\mathrm{c}}$ & 0.44 & 5.18 & 0.0 \\
Area 2 $^{\mathrm{a}}$ & 0.29 & 7.68 & 9.2 \\
Area 3 $^{\mathrm{c}}$ & 1.61 & 3.80 & 0.0 \\
Area 4 & 0.59 & 3.16 & 0.0 \\
Area 5 & 1.57 & 2.73 & 5.0 \\
Area 6 & 1.80 & 4.27 & 0.0
\end{tabular}

$\bar{a}$ Canatto (2010), b SINAN (2009), c Areas with stray dog population. 
When those variables were correlated to each other, only the variables with lower significance levels were used in the model fitting.

The models were produced for household levels and data on the dogs was summarised for each household as number of dogs with studied characteristics in the household (absolute frequency). The variables were only kept in the multiple analyses model if had a significance level below 0.05 (in the model). The analyses were performed in SPSS 9 and Stata 13.

\section{RESULTS}

Out of the six study areas, stray dogs were observed during the study only in areas 1 and 3 (Fig 1), whilst householders

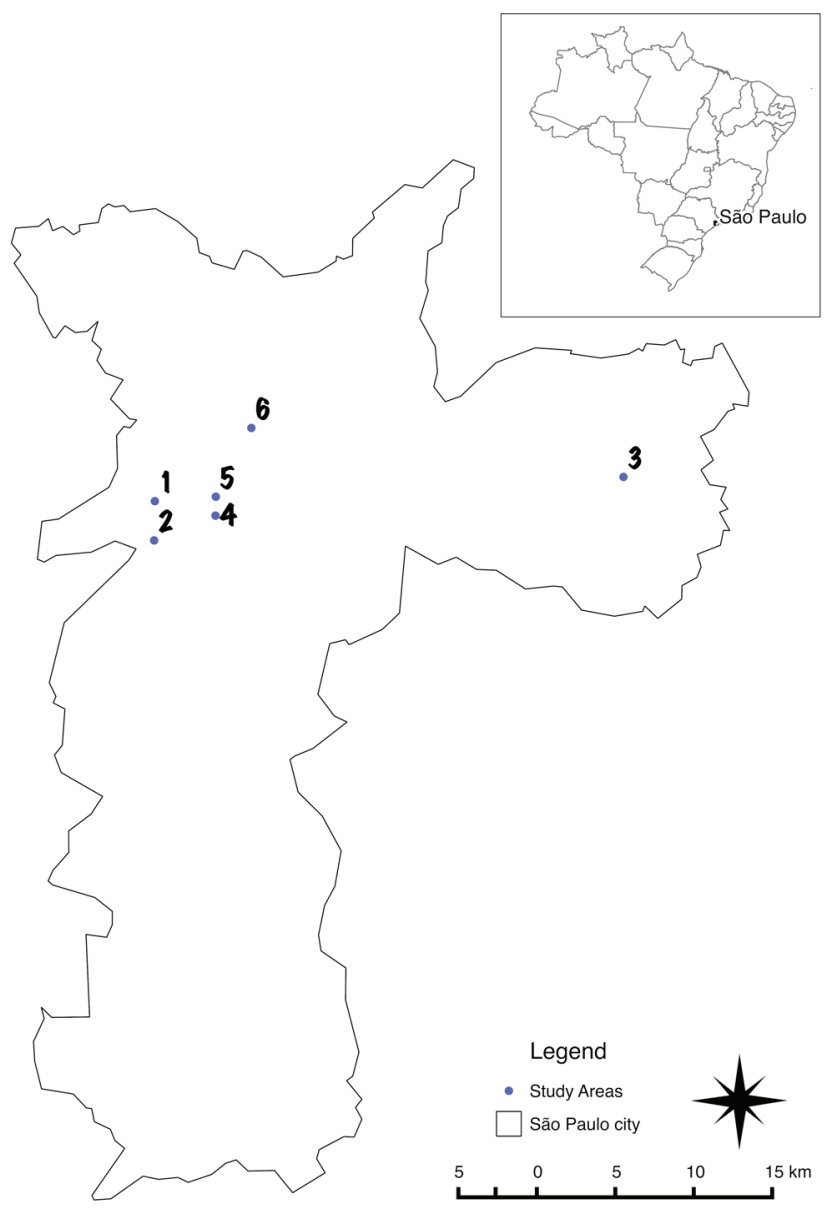

Fig.1. Location of the study areas in the city of São Paulo and its location in Brazil. of all six areas referred observing stray dogs in their neighborhood. Interviewed persons from areas 1 and 3 had a higher frequency of stray dogs sighting (65\% and 95\%, respectively) when compared to the other areas $(40 \%, 60 \%$, 30 and $25 \%$ ), but only area 3 had a significant difference when compared to areas 2, 5 and 6.

Areas 1 to 5 were mostly residential, while area 6 had many commercial buildings and was surrounded by an industrial area. In area 1 we found many student houses and sloppy terrain whereas in area 2 we found single story houses with garages and few gardens. Area 3 was an urban area surrounded by a less urbanised space. Area 4 had large houses with yards and tall fencing. Area 5 had two story houses with small total area. Area 6 had some apartment buildings, along with some houses. The description of these areas is presented in Table 2.

Owned dogs kept inside the household were more likely to have access to the street with supervision ( $\mathrm{p}=0.021)$. The dogs that were always taken with on family trips were more likely to be referred as purebred ( $p=0.025)$, being owned by people with more than 12 years of study $(\mathrm{p}=$ $0.006)$ and to be living in an apartment $(p=0.003)$ but those three characteristics are not related to each other. Seeing people feeding dogs was more frequent among those who saw food laid out for dogs $(\mathrm{p}<0.001)$.

No relinquishment factors were associated with householders observation of stray dogs at significance level of 0.05 . The relinquishment factors selected for multiple analysis are presented in Table 3 . There was no multiple model resulting from the analysis, and all variables still had significance levels above 0.05 after fitting. The variables eliminated from the model due to correlation with others that had higher significance level are also presented in Table 3.

Table 2. Area, street extension, route extension, number of households and the interval used in systematic random sampling of households in the study areas. São Paulo, 2011

\begin{tabular}{lccccc}
\hline Area & $\begin{array}{c}\text { Area } \\
\left.\text { (thousand } \mathrm{m}^{2}\right)\end{array}$ & $\begin{array}{c}\text { Streets } \\
(\mathrm{Km})\end{array}$ & $\begin{array}{c}\text { Route } \\
(\mathrm{Km})\end{array}$ & Households & Interval \\
\hline Area 1 $^{\mathrm{a}}$ & 151 & 3,56 & 4,10 & 386 & 20 \\
Area 2 $^{\text {Area 3 }}$ & 78 & 2,03 & 2,55 & 276 & 12 \\
Area 4 & 78 & 2,36 & 3,11 & 401 & 20 \\
Area 5 & 63 & 1,76 & 2,14 & 77 & 5 \\
Area 6 & 83 & 2,64 & 3,60 & 327 & 17 \\
\end{tabular}

$\overline{\text { a Areas with stray }}$ dog population.

Table 3. Variables with significance level under 0.2 showing their significance levels, data categorisation and if they were used in the forward selection of the multilevel mixed-effects Poisson regression model due to corruption with other variables. São Paulo, 2011

\begin{tabular}{|c|c|c|c|c|}
\hline Variables & Log Likelyhood & IRR & p value & Model \\
\hline Number of dogs not kept in the yard & -37.018343 & 0.5937 & 0.072 & Yes \\
\hline Household type being apartment & -99.231512 & 0.1693 & 0.081 & Yes \\
\hline Perception of food laid out for strays & -100.98451 & 1.5869 & 0.086 & Yes \\
\hline Number of dogs always taken along in family trips & -36.895997 & 0.3469 & 0.104 & No \\
\hline Owned dog have supervised access to the street. & -37.979388 & 0.7133 & 0.166 & No \\
\hline Number of pure breed dogs & -38.082757 & 0.6964 & 0.177 & Yes \\
\hline Dog caregiver having more than 12 years of study & -37.854517 & 0.6230 & 0.180 & Yes \\
\hline Perception of people feeding stray dogs in the study area & -101.56048 & 1.4313 & 0.187 & No \\
\hline Perception of garbage laid out in the streets of the study area & -99.839634 & 1.4493 & 0.192 & Yes \\
\hline
\end{tabular}




\section{DISCUSSION}

Obtaining data on abandonment trough personal interview was difficult, most likely because it is socially unaccepted and illegal in Brazil. People avoid talking about this, but it does not refrain the actions.

It is not possible to determine if the stray dogs observed in any area were abandoned by people living in those areas, despite the fact that areas with stray dogs had household with greater number of known relinquishment factors.

Some studies have shown that environmental carrying capacity has a key role in maintaining the dog population Dias et al. 2015, Baquero et al. 2016). Considering that, stray dogs in urban areas would depend on the availability of food, water and shelter. For these animals, the source of food may be variable between areas in the city as they seek food from garbage, restaurant waste and even from food bowls left intentionally for them. Dogs also present a high capacity of dispersion, increasing the probability to find food sources. In the urban environment of São Paulo, finding shelter may not be a problem for roaming dogs, as it is readily available in alleys, under parked cars and trucks, porches and stairs (Daniels 1983).

In areas where we found stray dogs, abandonment and sightings of abandoned animals occurred more frequently, as reported by householders. Although stray dogs have a dispersive behaviour, the regular presence of food and shelter resources can fixate those dogs in a given area and they can even show territorial behaviour (Dias et al. 2013). In these areas, the higher frequency of leftover or dog food, uncollected garbage and opened garbage bags may play a role on fixating the abandoned dogs. However, it is not possible to establish if the presence of these factors causes the permanence of dog or happen in consequence of their presence, since the dogs can also find resources in the neighbour areas.

The study was designed to evaluate relatively closed areas - surrounded by streets of high traffic volume, water bodies or other urban characteristic that would avoid the dogs from coming in or out very often. During the study it was observed this premise was not completely true, as dogs were observed easily crossing major avenues. This can be a limiting factor to evaluate this results and for this reason the presence of stray dogs was evaluated as it was described by the dwellers instead of the observed by researchers.

The type of residence apartment- is more frequent among those who see stray dogs less frequently. This could mean a different relation with the public space for those who live in apartments, or that those areas are less prone to have shelter on the street for the stray dogs.

The difference in owned dogs' access to the street between outcomes can indicate a difference in time and care dedicated to the pet. Recognizing the dogs' need to go walk but knowing the risk of unsupervised walks may be more common amongst owners in areas with less stray dogs. This lead to greater frequency of supervised dogs' access to the street in these areas.

Being kept inside the house and being taken on family trips may indicate the degree of proximity between dogs and humans, and are protective for the outcome. The place of maintenance was identified as a risk for relinquishmentdogs kept outside have greater risk (Salman et al. 1998).

Sighting of stray dogs was less frequent amongst those owners who referred to their own dogs as purebred, factor also protective for relinquishment Patronek et al. 1996, Salman et al. 1998, New Jr et al. 2000). This may reflect more thought and planning on the part of the family surrounding the acquisition of and subsequent care for the dog, as it implies an initial cost.

Despite the fact that none of the variables isolated or in the model had a significance lower that 0.05 , the variables used in the multiple regression $(>0.2)$ were those related to environmental factors, such as waste handling. Some social factors are also important and have an economic link, such as the dog being taken on family trips and being of purebred. All this factors pointing towards responsible ownership as a possible intervention point, are supported by other work that found sterilization as an important factor affecting size of stray population (Baquero et al. 2016) and owned population (Dias et al. 2015), right below carrying capacity. In Russia it was also proven that some incidents like runaway ou lost pets could play a key role in maintaining stray population and could account for 10 to $39 \%$ of total stray individuals (Makenov \& Bekova 2016).

\section{CONCLUSIONS}

The risk factors for relinquishment in Asia and USA are not determinants for the presence of stray dogs in Brazil.

In this study, the most important factors associated with the presence of stray dogs are the place where the owned dog is kept and the investment (of both money and time) toward this dog. The carrying capacity has a role in determining the population of roaming dogs, especially the uncollected garbage on the streets. This can be assessed by authorities, although may simply transfer the problem to another area, making the dogs to disperse.

The association of the environmental and social factors may be viewed from a cultural standpoint - perhaps a difference in the concept of animal welfare or the public space. In some areas a dog living in the streets was unacceptable, while in others it seems to be a natural fact.

Acknowledgements.- The authors acknowledge CAPES for the financial support through a master's degree scholarship, Bianca Davico Canatto for the great help given in the field work.

Conflict of interest statement.- The authors have no competing interests.

\section{REFERENCES}

Baquero O.S., Akamine L.A., Amaku M. \& Ferreira F. 2016. Defining priorities for dog population management through mathematical modeling. Prev. Vet, Med. 123:121-127.

Bec A.M. 1973. The Ecology of Stray Dogs: a study of free-ranging urban animals. Purdue University Press, West Lafayette, 98p.

Canatto B.D. 2010. Caracterização das populações de cães e gatos domiciliadas no município de São Paulo. Master's Dissertation in Experimental Epidemiology Applied to Zoonosis, Faculty of Veterinary Medicine and Animal Husbandry, University of São Paulo, São Paulo, SP. 9p.

Dalla Villa P., Kahn S., Stuardo L., Iannetti L., Di Nardo A. \& Serpell J.A. 
2010. Free-roaming dog control among OIE-member countries. Prev. Vet. Med. 97:58-63.

Daniels T.J. 1983. The social organization of free-ranging urban dogs: I. Non-estrous social behavior. Appl. Anim. Ethol. 10:341-363.

Dias R.A., Baquero O.S., Guilloux A.G.A., Moretti C.F., de Lucca T., Rodrigues L.C.A., Castagna C.L., Presotto D., Kronitzky Y.C., Grisi-Filho J.H.H., Ferreira F. \& Amaku M. 2015. Dog and cat management through sterilization: Implications forpopulation dynamics and veterinary public policies. Prev Vet Med. 122:154-163.

Dias R.A., Guilloux G.A.G., Borba M.R., Guarnieri M.C.L., Prist R., Ferreira F., Amaku M., Ferreira Neto J.S. \& Stevenson M. 2013. Size and spatial distribution of stray dog population in the University of São Paulo campus, Brazil. Prev. Vet. Med. 110(2):263-273.

IBGE 2015. Cidades São Paulo São Paulo. Instituto Brasileiro de Geografia e Estatística. Avaliable: <http://cidades.ibge.gov.br/xtras/perfil.php?lang $=\&$ codmun $=355030 \&$ search=sao-paulo|sao-paulo $>$ Visite: Jun03/ 2015.

Jöchle W. 1991. Pet population control in Europe. J. Am. Vet. Med. Assoc. 198(7):1225-1230.

Kato M., Yamamoto H., Inukai Y. \& Kira S. 2003. Survey of the stray dog population and the health education program on the prevention of dog bites and dog-acquired infections: A comparative study in Nepal and Okayama prefecture, Japan. Acta Med. Okayama 57(5):261-266

Kidd A.H., Kidd R.M. \& George C.C. 1992. Successful and unsuccessful pet adoptions. Psychol. Rep. 70:547-561

Marder A. \& Duxbury M.M. 2008. Obtaining a pet: realistic expectations, Vet. Clin. North Am., Small Anim. Pract. 38(5):1145-1162

Makenov M.T. \& Bekova S.K. 2016. Demography of domestic dog popula- tion and its implications for stray dog abundance: a case study of Omsk, Russia. Urban Ecosyst. 19(3):1405-1418.

New Jr J.C., Salman M.D., King M., Scarlett J.M., Kass P.H. \& Hutchison J.M. 2000. Characteristic of shelter-relinquished animals and their owners compared with animals and their owners in U.S. pet-owning households. J. Appl. Anim. Welfare Sci. 3(3):179-201

Patronek G.J., Glicman L.T., Beck A.M., Mccabe G.P. \& Ecker C. 1996. Risk factors for relinquishment of dogs to an animal shelter. J. Am. Vet. Med. Assoc. 209:572-581.

Pozzetti P.S. 2001. Estudo epidemiológico da raiva em animais herbívoros, no Estado de São Paulo, nos anos de 1996 a 1999. PhD Thesis in Experimental Epidemiology Applied to Zoonosis Faculty of Veterinary Medicine and Animal Husbandry, University of São Paulo, São Paulo, SP. 37p.

Reece J.F., Chawala S.K., Hiby E.F. \& Hiby L.R. 2008. Fecundity and longevity of roaming dogs in Jaipur, India. BMC Vet. Res. 4(6):1-7.

Rubin H.D. \& Beck A.M. 1982. Ecological behavior of free-ranging urban pet dogs. Appl. Anim. Ethol. 8:161-168.

Salman M.D., New Jr J.G., Scarlett J.M., Kass P.H., Ruch-Gallie R. \& Hetts S. 1998. Human and animal factors related to the relinquishment of dogs and cats in 12 selected animal shelters in the United States. J. Appl. Anim. Welfare Sci. 1(3):207-226.

SINAN 2009. Sistema de Informação de Agravos de Notificação. Relatório, Sinan, Brasília. Avaliasse at <http://covisa.prodam/cgi-win/deftohtm. exe?SINANNET/AntirabNET.def > Visited May 3, 2009

Weng H.Y., Kass P.H., Hart L.A. \& Chomel B.B. 2006. Risk factors for unsuccessful dog ownership: an epidemiologic study in Taiwan. Prev. Vet. Med. 77:82-85. 